\title{
ECOLOGICAL AND ECONOMIC EFFICIENCY OF PEAT FAST PYROLYSIS PROJECTS AS AN ALTERNATIVE SOURCE OF RAW ENERGY RESOURCES
}

\author{
Pavel Tcvetkov ${ }^{1}$, Alexey Strizhenok ${ }^{1}$ \\ 1 National Mineral Resources University (Mining University), Vasilyevsky Island 21 line d.2, Saint-Petersburg, \\ 199106, Russia, e-mail: pscvetkov@yandex.ru; alexeystrizhenok@mail.ru
}

Received: 2015.11.19

Accepted: 2015.12.09

Published: 2016.01.06

\begin{abstract}
The objective of this review is to find ecologically and economically reasonable method of biomass processing to produce electricity and thermal energy. The major causes of the annual increase in the volume of consumed electricity and thermal energy are the current pace of scientific and technological progress, the overcrowding of cities and industrial agglomeration. Traditional energy sources (coal, oil, gas) have a significant negative impact on the environment, which leads to the deterioration of sanitaryhygienic indicators of the human environment. Besides, prices for traditional energy resources are increasing due to the decline of easy produced stocks. The goal of this article is the investigation and evaluation of environmental and economic efficiency of biomass fast pyrolysis methods for as modern energy resources. The result of the review is the choice of biomass fast pyrolysis as the most environmentally reasonable and economically viable local method of producing electricity and thermal energy in Russia. This method is more eco-friendly, compared to other alternative energy sources, for example using peat as solid fuel.
\end{abstract}

Keywords: pollution, environment, waste, biomass, energy, pyrolysis, peat, Russia.

\section{INTRODUCTION}

Energy efficiency and energy safety of population, enterprises and regions are relevant issues for modern economies. At the same time, constant increasing rate of energy enterprises production reflects the quantity of emissions, discharges and disposal of fuel combustion waste (ash) what is the reason of comprehensive and concentrated negative impact on all the components of the environment. Moreover, the situation in energy resource's market is characterized by a stable growth of prices and volumes of demand decrease the value of easy oil reserves and other traditional energy resources, a tendency of ensuring the energy independence of individual regions. In this regard, researches in the field of finding alternative energy sources, known as renewable energy sources (renewables), are proliferated [Energy Policy... 2009]. Using renewables can reduce technogenic impact of energy enterprises on the environment, which is constantly growing, and solve the problem of energy supply in developing countries.

Logically, renewables could be divided in two groups: inexhaustible sources of energy and biological sources.

Technologies, based on inexhaustible sources of energy, include solar panels, hydroelectric power plants, wind power plants and geothermal power plants. These sources are clean and completely safe for the environment, but at the present stage of science and technology development, the efficiency of such plants is significantly lower than their traditional analogs (plants based on oil, coal and gas) [Turner et al. 2013]. Moreover, the development of such technologies depends on rare-earth elements, which have comparatively high price and limited supply in world markets [Cherepovitsyn et al. 2015]. Despite this, many developed countries, which have environmental safety on high level, provide up to $40 \%$ of national electricity demand due to the use of these sources [Renewables Report 2014]. It becomes 
possible in condition of strict state regulation in the field of interaction between energy companies and the environment. Among the leaders are Denmark, United Kingdom, Scotland, Ireland etc.

Another promising area of energy development is the use of biomass as a fuel feedstock [Eikhout et al. 2012]. Biomass includes wastes, wood, peat etc. A simple burning of biomass for obtaining thermal energy if enough common, but not effective approach [Reiley et al. 2013]. Enterprises with such technological cycle are almost non-competitive in regional market without a significant state support [Clarke et al. 2010]. The advantage of using biomass over traditional types of fuels is that the common environmental situation in surrounding plant areas is much better and it is much cheaper than using inexhaustible sources of energy. The world leader in production energy from peat is Finland, where over $60 \%$ of country's energy balance consists of peat [Wiser et. al. 2010].

Researches [Review of Finnish Biomass... 2002, Hörnell 2001, Lédé 2013] show that efficiency of using biomass as feedstock can be increased significantly [Lazar et al. 2012] by implementation of deep processing technologies, and, as a result, bio-energy enterprises could improve their competitiveness and stability. For example, the deep processing of peat allows, in addition to the thermal energy production, to receive a number of by-products: synthetic gas, synthetic oil, high-carbon materials and others [Lehto 2014].

Technologies of deep peat processing cause debate among environmentalists, because there is no clear opinion about their impact on environmental components (including the combustion of synthetic products). At the same time, there are no ways to determine the degree of anthropogenic impact by monitoring atmospheric air in Russia due to a small number of such enterprises.

According to the results showed in [Industry Social Responsibility Report 2014], enterprises of deep peat processing are environmentally clean industrial objects. In addition, the extraction and processing of peat helps to avoid fire situations during the dry seasons.

Despite the presence of technical and technological base, the issues of environmental and economic efficiency of deep peat processing are not sufficiently analyzed in scientific literature. In this study, the environmental and economic efficiency of deep peat processing technologies was assessed on the base of Russian developments.
It should be noted that the production process of deep biomass processing is similar to different kinds of feedstock (peat, wood and other bio-resources). Significant differences are in the list of possible products produced from various raw materials. However, if production of thermal energy (by combustion of biomass) and synthesis gas (for further production of electricity) is the main aim of the enterprise, the feedstock of techniques discussed below can be changed.

\section{MATERIALS AND METHODS}

Promising researches in the field of deep peat processing (gasification) are carried out in many countries, among them there are studies of scientists from the USA [Jones et al. 2013, Ringer et al. 2006, Wright et al. 2010], Finland [Oasmaa et al. 2010], UK [Brownsort 2009], Australia [Jahirul et al. 2012] and other countries. However, there are no researches of Russian scientists in the international scientific publications, despite the fact that the volume of peat reserves [Mineral Commodity Summaries 2015] and the potential of its use [Bächtold 2012] in Russian Federation are the largest in the world [Timofeeva et al. 2014].

This review is based on the analysis of Russian developments in the field of alternative energy sources production by using the technology of fast peat pyrolysis. Final products according to this technology are synthetic oil, synthesis gas and thermal energy.

Pyrolysis is the process of thermal decomposition of organic compounds derived without oxygen at temperatures up to $850^{\circ} \mathrm{C}$ [Tolvanen et al. 2013]. Pyrolysis (depending on the heating rate) is divided into fast, intermediate and slow. Due to the fact that fast pyrolysis has considerable advantages [Haoxi et al. 2013], in comparison with other types, the evaluation represented in this review is based on it.

The technical information for calculation of economic and ecological efficiency is contained in four patents of Russian scientists [Kotelnikov et al. 2004, Titov et al. 2009, Kotelnikov et al. 2007, Baybursky et al. 2011], which are representing a technology of peat processing on the basis of fast pyrolysis process. This paper shows an attempt to evaluate environmental and economic efficiency of peat fast pyrolysis technology based on the averaged data, given that the input parameters of the considered technologies, in general, 
similar to each other. It will allow getting a more accurate view of the applicability of such technologies. For calculation, the following assumptions were attempted:

1. Annual production capacity of the peat (humidity is about $50 \%$ ) is 30 thousand tons. The recycling process is divided into 2 stages [Titov et al. 2009]. The first stage is peat drying (moisture content of peat on the output $1-2.5 \%$ ), the second is temperature rise and the production of synthetic oil. The yield of the final product are 0.5 cubic meters of synthesis gas, 20 grams of synthetic oil and 2.5 gigacalories of thermal energy from 1 kilogram of dry peat (moisture content 2\%) [Kotelnikov et al. 2007].

2. Capital costs are 1,204 million USD ( 80 million rubles at the exchange rate of the Central Bank of the Russian Federation on 29.11.2015). The life of the equipment is 10 years. The method of depreciation is linear ( $10 \%$ per year). The price of raw materials and materials adopted based on the average. The number of personnel required for the operation of the enterprise is equal to 9 units, including a business executive and an accountant [Baybursky et al. 2011]. The level of wages is adopted on the basis of the national average [Trading Economics Review 2015]. Cost allocation by final product: synthetic oil $-20 \%$, the synthesis gas $-30 \%$, thermal energy $-50 \%$ [Baybursky et al. 2011]. Rates and the list of tax payments are made on the basis of the legislation of the Russian Federation [Russian Federation Tax Code 2015]. Sales quantities are taken equal to the volume of production. The cost of the final product is set on $15-30 \%$ below than market average cost [Oil and Gas Market Research 2015].

3. The period of calculation of the project economic efficiency (including construction stage -8 months) -7 years. The rate of discount when evaluating the project estimated to be equal to $23 \%$ since there is a decline of the peat industry, imperfect system of legal regulation of the industry, high interest rates and inflation, as well as unstable economic and political situation today in Russia. Start date of construction works is 12.01.2016. The project>s launch date is 12.09.2016.

4. Calculation of environmental efficiency shows that the emissions to air from the proposed technology will be significantly lower than combustion of traditional energy sources (oil, coal) and comparable with the energy companies, operating on natural gas (however, there are no hydrocarbon emissions in the process of peat pyrolysis). Thus, the fee for emissions from the combustion of biomass and synthesis gas (assuming no gas-cleaning equipment in all enterprises) may be reduced 7 times, compared with oil, 2.5-4 times compared with coal, and up to 1.5 times compared with natural gas, even taking into account the imperfections of the legislative base in the field of environmental protection in Russia [Kopylov et al. 2012].

\section{RESULTS AND DISCUSSION}

The performed calculation shows that economic efficiency of peat fast pyrolysis projects is closely connected with regional and national policies in tax field, with the price of peat and with rate of wage, because these three elements form about $95 \%$ of operational costs (Figure 1). It shows the importance of geographical location for founding such enterprises.

The obtained products are superior to analogues and are competitive in the international market of energy resources (Table 1).

Given that the qualitative characteristics of the obtained products (synthetic oil and syngas) are comparable with their "original" analogues, the project is characterized by high values of economic efficiency indicators (Table 2).

Speaking about the potential transition from traditional energy sources it should be noted that the quality of the final product can vary significantly, depending on the technology. So, the heat of combustion of the synthetic gas is in the range between 25 (comparable to coal) and $33 \mathrm{MJ} / \mathrm{m}^{3}$ (which is essentially equivalent to the heat of natural gas combustion) [Demirel 2012].

As mentioned earlier, the technology of fast pyrolysis is developed not only for peat. For example, substitution of peat for wood waste in Russia will allow reducing the cost of procurement of raw materials by almost 10 times [Gray 2015], but the qualitative characteristics of the final product will be lower [Link et. al. 2013]. The main factors determining the feasibility of using particular types of energy resources are geographic spread in the region of consumption (for Russia most relevant sources are peat and wood waste) and market conditions for the sale of by-products (presence infrastructure). 


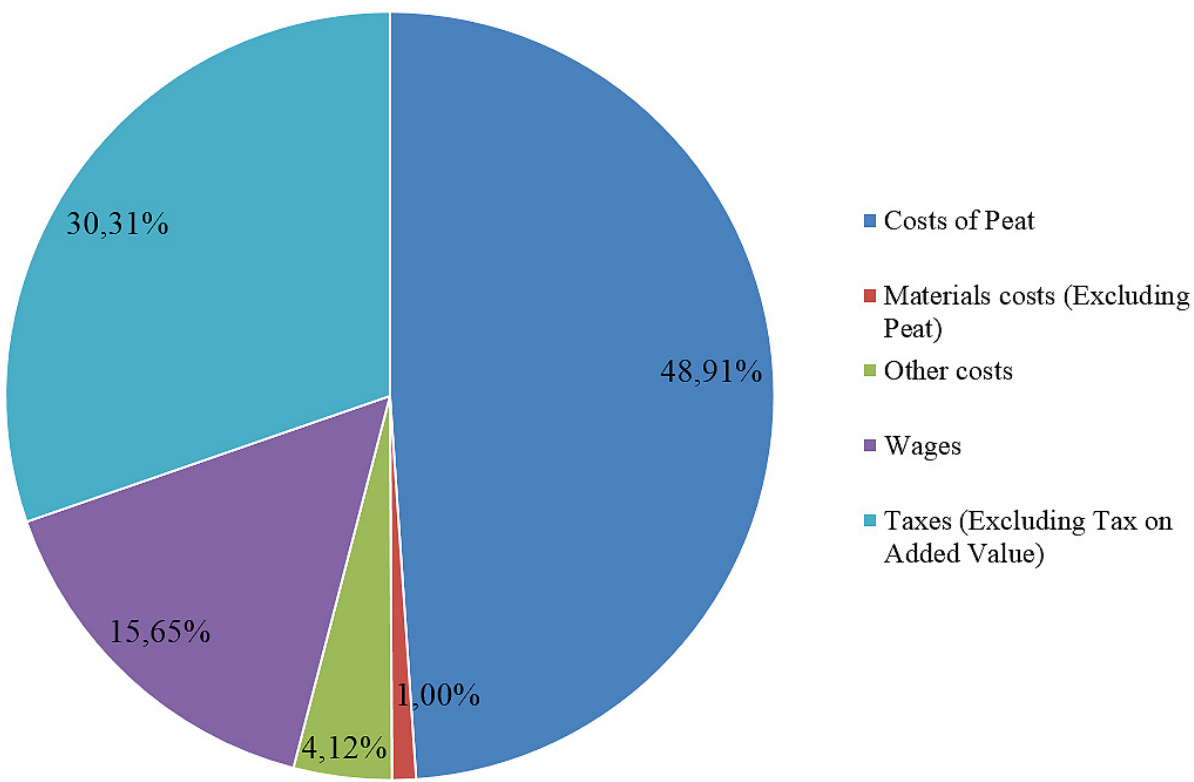

Figure 1. Structure of operational costs

Table 1. The value indicators of the final products

\begin{tabular}{|l|l|c|c|c|c|}
\hline \multicolumn{1}{|c|}{ Product } & \multicolumn{1}{|c|}{ Units } & $\begin{array}{c}\text { Production volume } \\
\text { per year }\end{array}$ & $\begin{array}{c}\text { The cost (excluding } \\
\text { logistics expenses) [USD] }\end{array}$ & $\begin{array}{c}\text { Sales price } \\
\text { [USD] }\end{array}$ & $\begin{array}{c}\text { Return on } \\
\text { margin [\%] }\end{array}$ \\
\hline Synthetic oil & Tons & 3000 & 28.3 & 37.62 & 32.8 \\
\hline Synthesis gas & Thousand cubic meters & 7920 & 16.1 & 30.10 & 87.0 \\
\hline Thermal energy & Gigacalories & 37200 & 5.7 & 12.04 & 110.8 \\
\hline
\end{tabular}

Table 2. Indicators of economic efficiency of deep peat processing project in Russian conditions

\begin{tabular}{|l|c|c|}
\hline \multicolumn{1}{|c|}{ Indicator } & Units & Value \\
\hline Capital investments & Million USD & 1.204 \\
\hline Payback period & Years & 3.57 \\
\hline Discount rate & $\%$ & 23 \\
\hline Discounted payback period & Years & 5.3 \\
\hline Internal rate of return & $\%$ & 34.48 \\
\hline Profitability index & - & 1.22 \\
\hline
\end{tabular}

Briquetted peat as a solid fuel to produce thermal energy is used in Russia today. This technology is more environmentally friendly than using some types of traditional energy resources (shale, oil products), however, the specific calorific value of peat is lower than traditional energy sources, and waste generates much more (fly ash) in the process of peat combustion [Shtin 2011]. It makes using of the briquetted peat economically and environmentally feasible. The conducted review shows that the proposed method of peat fast pyrolysis will significantly reduce the anthropogenic pollution on the territory which is impacted of the enterprise for deep processing of peat, not only in comparison with traditional energy resources, but also with some alternative energy resources, for example briquetted peat. In addition, the proposed method gives the possibility of processing waste products of wood, pulp and paper and other industries, which contributes to the reduction in the area occupied by industrial waste [Kopylov et al. 2012]. Thus, the transfer of energy enterprises from peat to synthetic gas or synthetic crude oil, which are the result of deep peat processing, is not only environmentally reasonable but also an economically viable solution.

\section{CONCLUSIONS}

The implementation of energy projects is a prerequisite for the development of any region [Wlokas et al. 2012, Demirta 2013, Reza Asadi et al. 2012, Uduma et al. 2010]. The possibility of using the peat pyrolysis technology, analyzed by authors, will reduce the dependence of the economy from traditional energy resources, to reduce the considerable anthropogenic pollution of environment by energy enterprises, and to provide the population with ecologically pure energy. For example, ecologically 
pure energy amounted to 1064,96 billion $\mathrm{kWh}$ (109\% compared with 2009) in 2014 in Russia [Russian Industrial Production 2015].

The presented results of calculation could be characterized as common, due to this, the evaluation of feasibility of such projects implementation should take into consideration the regional specific, including, for example, the cost of necessary raw materials. For example, to implement the project in Russia, about $50 \%$ of the operational costs will be the cost of peat (Figure 1).

The practical significance of such projects is presented in four main directions:

1. The implementation of the project, discussed in the paper, on the example of the existing industries is used for reducing their dependence on supplies of energy resources from thirdparty organizations. The cost of production of thousand cubic meters of synthesis gas, on the example of reviewed projects, is 20 USD, while the price of natural gas could reach 300 USD and it is constantly raising [Energy Strategy of Russia... 2010].

2. A significant reduction of negative impacts on environmental components is attained due to the use of cleaner and low-waste technologies. Payment for pollution of environment and storage of waste can be reduced from 5 to 20 times in comparison with using conventional energy resources.

3. The creation of new local energy enterprises makes it possible to meet the needs of the population of regions for gas and electricity.

4. Peat processing allows obtaining some byproducts: thermal energy, high-carbon materials, synthetic oil, ash and other in addition to the production of synthesis gas. This will ensure the diversity of new enterprises, increase their competitiveness and sustainability, as well as create a database to meet the demand for raw materials of certain industries.

\section{Acknowledgements}

The paper is based on research carried out with the financial support of the grant of the Russian Science Foundation (Project No. 14-3800009, "The program-targeted management of the Russian Arctic zone development"). Peter the Great St. Petersburg Polytechnic University.

\section{REFERENCES}

1. Bächtold J. 2012. Russia Renewable Energy. URL: http://www.s-ge.com/de/filefieldprivate/files/53139/ field_blog_public_files/14171 (02.12.2015).

2. Brownsort P. 2009. Biomass pyrolysis processes: review of scope, control and variability. UKBRC Working paper, 5. URL: www.biochar.ac.uk/download.php?id=14 (02.12.2015).

3. Cherepovitsyn A.E., Fedoseev S.V., Teslya A.B., Vyboldina E.Y. 2015. Analysis of production and consumption of rare-earth metals in the EU and the BRICS. Tsvetnye Metally, 5, 5-10. DOI: 10.17580/ tsm.2015.05.01.

4. Clarke D., Rieley J. 2012. Strategy for responsible peatland management. Amsterdam. URL: http:// www.bordnamona.ie/wp-content/uploads/2012/07/ Strategy-for-Responsible-Peatland-Management. $\operatorname{pdf}(02.12 .2015)$.

5. Demirel Y. 2012. Energy: production, conversion, storage, conservation, and coupling. Springer. Berlin Heidelberg. 2012. URL: http://www.springer. $\mathrm{com} / \mathrm{cn} /$ book/9781447123712 (13.12.2015).

6. Demirta O. Evaluating the best renewable energy technology for sustainable energy plannin. International Journal of Energy Economics and Policy, 3. URL: http://www.econjournals.com/index.php/ ijeep/article/view/571 (13.12.2015)

7. Eikhout B.A. 2012. Strategy for a bio-based economy. Green European Foundation. Belgium. URL: http://gef.eu/uploads/media/A_strategy_for_ a_bio-based_economy.pdf (02.12.2015).

8. Energy Policy of Poland until 2030. Warsaw 10 November 2009. URL: http://www.mg.gov.pl/ files/upload/8134/Polityka $\% 20$ energetyczna $\% 20$ ost_en.pdf (02.12.2015)

9. Energy Strategy of Russia for the period up to 2030. Institute of Energy Strategy, 2010. URL: http://www.energystrategy.ru/projects/docs/ES2030_(Eng).pdf (13.12.2015).

10. Russian industrial production. Federal State Statistics Service of Russia. URL: http:/www.gks. $\mathrm{ru} / \mathrm{wps} / \mathrm{wcm} /$ connect/rosstat_main/rosstat/ru/statistics/enterprise/industrial/\# (02.12.2015).

11. Global Oil \& Gas Exploration \& Production: Market Research Report. 2015. URL: http://www.ibisworld.com/industry/global/global-oil-gas-exploration-production.html (02.12.2015).

12. Gray R. Biofuels Annual. Russian Federation. RS1543. 7/1/2015. URL: http://gain.fas.usda. gov/Recent\%20GAIN\%20Publications/Biofuels\%20Annual_Moscow_Russian\%20Federation_7-1-2015.pdf (13.12.2015).

13. Haoxi B., Arthur J., Ragauskas A. 2013. Comparison for the compositions of fast and slow py- 
rolysis oils by NMR characterization. Bioresource Technology, 8(147C), 577-584. DOI: 10.1016/j. biortech.2013.07.151.

14. Hörnell C. 2001. Thermochemical and catalytic upgrading in a fuel context: peat, biomass and alkenes. Doctoral dissertation, Kungliga Tekniska Högskolan, Stockholm, Sweden, 87 p. URL: http:// www.diva-portal.org/smash/get/diva2\%3A8931/ FULLTEXT01.pdf (02.12.2015).

15. Industry Social Responsibility Report 2014. Canadian Sphagnum Peat Moss Association. Alberta, Canada, URL: http://tourbehorticole.com/wp-content/up loads/2015/07/CSPMA_ISR_Report_2014_web_ LW.pdf (02.12.2015).

16. Jahirul M., Rasul M., Chowdhury A., Ashwath N. 2012. Biofuels production through biomass pyrolysis - A technological review. Energies, 5, 4952-5001.

17. Jones S., Meyer P., Snowden-Swan L. 2013. Process design and economics for the conversion of lignocellulosic biomass to hydrocarbon fuels. U.S. Department of Energy, Bioenergy Technologies Office. URL: http://www.pnnl.gov/main/publications/external/technical_reports/PNNL-23053.pdf (02.12.2015).

18. Kopylov A.E., Zerchaninov I.L. 2012. Gasification of solid fuels: a retrospective review, current situation and prospects of development. Moscow: InfraInzhenerija, $504 \mathrm{p}$.

19. Lazar M., Lengeyelova M., Kurilla P. 2012. Experiment of peat gasification in plazma reactor. The Holistic Approach to Environment, 4. URL: http:// www.cpo.hr/ Paper\%2032.pdf (09.11.2015).

20. Lédé J. 2013. Biomass fast pyrolysis reactors: a review of a few scientific challenges and of related recommended research topics. Oil Gas Sci. Technol. - Rev. IFP Energies nouvelles, 68(5), 801-814 DOI: http://dx.DOI.org/10.2516/ogst/2013108 (02.12.2015)

21. Lehto J., Oasmaa A., Solantausta Y., Kyto M., Chiaramonti D. 2014. Review of fuel oil quality and combustion of fast pyrolysis bio-oils from lignocellulosic biomass. Applied Energy, 116(1), 178-190. DOI: 10.1016/j.apenergy (04.11.2013).

22. Link S., Kask Ü., Paist A, Siirde A., Arvelakis S., Hupa M, Yrjas P., Külaots I. 2013. Reed as a gasification fuel: a comparison with woody fuels. Mires and Peat, 1, 1-12.

23. Reza Asadi Asad Abad M., Moharrampour M., Abdollahian H., Shir Ali M., Mohagheghzadeh F.. 2012. Developing renewable energies in Iran. International Journal of Energy, Information and Communications, 3(2), http://www.sersc.org/journals/IJEIC/vol3_Is2/2.pdf

24. Oasmaa A., Peacocke C. 2010. Properties and fuel use of biomass-derived fast pyrolysis liquids: A guide. Conversion and Resource Evaluation Ltd. VTT Publications. Espoo 2010. URL: http://www. vtt.fi/Documents/P731.pdf (02.12.2015).

25. Renewables Global Status Report REN21, 2014 (Paris: REN21 Secretariat). URL: http://www.ren21. net/Portals/0/documents/Resources/GSR/2014/ GSR2014_full\%20report_low\%20res.pdf.

26. Review of Finnish Biomass Gasification Technologies. OPET Report 4. Technical Research Center of Finland. Espoo 2002. URL: http://www.ieatask33. org/app/webroot/files/file/publications/OPETReport4gasification.pdf (02.12.2015).

27. RF patent No. 2259385. Kotelnikov V.A., Podzorov A.I. 2004. The method of processing of peat. The Patent of the Russian Federation. URL: http://www.findpatent.ru/patent/225/2259385.html (02.12.2015).

28. RF patent No. 2293104. Kotelnikov V.A., Podzorov A.I., Kotelnikov A.V., Zamuraev V.D. 2007. Fast pyrolysis of peat reactor. The Patent of the Russian Federation. URL: http://www.findpatent. $\mathrm{ru} /$ patent/229/2293104.html (02.12.2015).

29. RF patent No. 2414503. Baybursky V.L., Males G.S., Nightshade V.N. 2011. Installation for producing synthesis gas by pyrolysis of solid carbonaceous raw materials. The Patent of the Russian Federation. URL: http://www.findpatent.ru/patent/241/2414503.html (02.12.2015).

30. RF patent No. 2352606. Titov A.N. 2009. Method of processing of organic raw materials by pyrolysis. The Patent of the Russian Federation. URL: http://www.findpatent.ru/patent/235/2352606.html (02.12.2015).

31. Rieley J., Silpola J., Warnecke S. Peat. 2013. World Energy Resources 2013 Survey. World Energy Council. URL: https://www.worldenergy.org/wp-content/uploads/2013/09/Complete_WER_2013 Survey.pdf (02.12.2015).

32. Ringer M., Putshe V., Scahill J. 2006. Large-scale pyrolysis oil production: a technology assessment and economic analysis. National Renewable Energy Laboratory. Technical NREL/ TP-510-377779, 01.2006.

33. Russia Average Monthly Nominal Wages in Manufacturing. Trading Economics. 2015. URL: http:// www.tradingeconomics.com/russia/wages-inmanufacturing (02.12.2015).

34. Shtin S.M. 2011. Peat application as fuel for small power. GIAB No. 7. Publisher of MGGU, 82-96.

35. Tax code of Russia with Changes and Additions. 2015. URL: http://base.garant.ru/10900200 /1/\#block_11111 (02.12.2015).

36. Timofeeva S.S., Mingaleeva G.R. 2014. Prospect of using peat in regional power engeneering. Izvestiya Tomskogo Polytechnicheskogo Universiteta. Tehnika i Tehnologii v Energetike. Tomsk, Tom 
325. No. 4. URL: http://www.lib.tpu.ru/fulltext/v/ Bulletin_TPU/2014/v325/i4/06.pdf (02.12.2015).

37. Tolvanen H., Kokko L., Raiko R. 2013. Fast pyrolysis of coal, peat, and torrefied wood: Mass loss study with a drop tube reactor, particle geometry analysis, and kinetics modeling. Fuel, 111, 148156. DOI: $10.1016 /$ j.fuel.2013.04.030.

38. Turner G. 2013. Global Renewable Energy Market Outlook 2013. Bloomberg New Energy Finance. 26 April 2013. URL: http://about.bnef.com/content/uploads/sites/4/2013/04/Global-Renewable-Energy-Market-Outlook-2013.pdf (02.12.2015).

39. Uduma K, Arciszewski T. 2010. Sustainable energy development: The key to a stable Nigeria. Sustainability, 2(6), 1558-1570. DOI: 10.3390/su2061558

40. U.S. Geological Survey. Mineral Commodity Summaries. January 2015. URL: http://minerals. usgs.gov/minerals/pubs/commodity/peat/mcs2015-peat.pdf (02.12.2015).
41. Wiser R., Yang Z., Hand M., Hohmeyer O., Infield D., Jensen P.H., Nikolaev V., O’Malley M., Sinden G., Zervos A. 2011. Wind energy. In: IPCC Special Report on Renewable Energy Sources and Climate Change Mitigation, Cambridge University Press, United Kingdom and New York, USA.

42. Wlokas H.L., Boyd A., Andolfi M. 2012. Challenges for local community development in private sector-led renewable energy projects in South Africa: An evolving approach. Journal of Energy in Southern Africa, 23(4), 46-51. URL: http://www. erc.uct.ac.za/jesa/volume23/23-4jesa-wlokas-etal. pdf (13.12.2015)

43. Wright M.M., Satrio J.A., Brown R.C., Daugaard D.E., Hsu D.D. 2010. Techno-economic analysis of biomass pyrolysis to transportation fuels. National Renewable Energy Laboratory. Technical NREL/ TP-6A20-46586, November 2010. URL: http://www. nrel.gov/docs/fy11osti/46586.pdf(02.12.2015). 